\title{
Chemical Compositions and Nematicidal Activities of Essential Oils on Meloidogyne hapla (Nematoda: Tylenchida) Under Laboratory Conditions
}

\author{
Ju-Hyun Jeon ${ }^{1,2}$, Hyoung-Rai Ko ${ }^{1}$, Se-Jong Kim ${ }^{1}$ and Jae-Kook Lee ${ }^{1, *}$ \\ Crop Protection Division, Department of Agro-food Safety and Crop Protection, \\ National Institute of Agricultural Sciences, RDA \\ ${ }^{2}$ KM-Convergence Research Division, Korea Institute of Oriental Medicine \\ (Received on November 20, 2015. Revised on February 22, 2016. Accepted on February 28, 2016)
}

\begin{abstract}
To evaluate the efficacy of natural nematicides for the control of root-knot nematode in strawberry greenhouses, commercial essential oils were examined by 24 -well culture plate bioassay for their nematicidal activities against second-stage juveniles and eggs of Meloidogyne hapla. Based on the mortality of $M$. hapla juveniles at a concentration of $125 \mu \mathrm{g} / \mathrm{mL}$, the most active essential oil was Alpinia galanga (100\%), followed by Carum carbi (22.3\%), Eugenia caryophyllata $(9.4 \%)$, Cinnamonum zeylanicum (7.2\%), Mentha pulegium (2.4\%), and Foeniculum vulgare (2.1\%). Moreover, A. galanga significantly reduced hatching at 7, 14, and 21 days after treatment. The volatile constituents identified in the $A$. galangal oil were methyl cinnamate $(87.4 \%), 1,8$-cineole $(4.4 \%), \beta$-pinene $(2.5 \%), \alpha$-pinene $(2.2 \%)$, and $p$-cymene $(1.1 \%)$, as major constituents. Results of this study show that $A$. galangal essential oil and its major constituents may serve as an environmental friendly agent of a promising natural nematicide to control Meloidogyne spp.
\end{abstract}

Key words Alpina galanga, Meloidogyne hapla, Natural nematicide, Plant essential oil

\section{Introduction}

Today, increasing public awareness of the environmental effects of chemical pesticides, health hazards, and adverse effects on non-target organisms becomes more critical on continued use of synthetic nematicides (Pandey et al., 2000; Hong et al., 2010). These undesirable effects highlight the need for application of selective nematode control alternatives, because chemical nematicides such as 1,2-dibromo-3chloropropane (DBCP) and 1,2-dibromoethane (ethylene dibromide) have been reserved from the agricultural chemical market due to their harmful effects on human health (Oka et al., 2000; Hong et al., 2010). It is necessary to develop new alternative control strategies for plant-parasitic nematodes, especially those with fumigant action in soil, because powders formulation are usually less effective and do not adequately penetrate deep layers (Hong et al., 2010). One

*Corresponding author

E-mail: jk2lee@korea.kr possible alternative is utilization of natural pesticides based on plant-derived extracts such as essential oils or other nematicidal sources from plants (Chitwood, 2002; Nguyen et al., 2013; Kim et al., 2014). Consequently a large number of plants (flowers, leaves, and rhizomes) have been experimented for their nematicidal effects (Pandey et al., 2000). However, nematicidal effects of essential oils and its volatile constituents against Meloidogyne hapla have not been reported. In our present study, plant essential oils from nine species were evaluated for their nematicidal and hatching inhibition activities against $M$. hapla second-stage juveniles (J2) and eggs under laboratory conditions. We also analyze the volatile compounds of essential oil extracted from Alpinia galanga rhizomes.

\section{Materials and Methods}

\section{Essential oils}

Nine plant essential oils (Alpinia galanga, Carum carbi, Cinnamonum zeylanicum, Eugenia caryophyllata, Foeniculum 
vulgare, Lavandula intermedia cv. Grosso, Melaleuca viridiflora, Mentha pulegium, and Myristica fragrans) were purchased from a local herb market, Skinmate (Bucheon, Korea) and stored in a glass bottle at $4^{\circ} \mathrm{C}$. Triton $\mathrm{X}-100$ was supplied by Fluka (Buchs, Switzerland).

\section{Nematode}

Meoloidogyne hapla, originally extracted from a strawberry field in Gongju (Chungnam province, South Korea), was cultured on tomato (Lycopersicon esculentum cv. Rutgers) in a glasshouse. Egg masses were isolated from plant roots, collected in water, and sterilized by agitation for $3 \mathrm{~min}$ in $1 \%$ sodium hypochlorite $(\mathrm{NaOCl})$ solution (Kim et al., 2014). The eggs were collected on a 500 mesh sieve, refrigerated overnight at $4^{\circ} \mathrm{C}$ in sterile distilled water and used for bioassay. Juveniles were obtained by Baermann funnel method (Barker, 1985), and used in this study were less than 5 days old.

\section{Bioassay}

The nematicidal activity of essential oils against $M$. hapla second-stage juveniles (J2) was evaluated by 24-well culture plate bioassay as described previously (Kim and Whang, 2012). The test solution containing 120 to $150 \mathrm{~J} 2$ per 0.98 $\mathrm{mL}$ of distilled water was prepared by diluting the test solution. Nematodes were placed in each well prior to adding the essential oils. Four concentrations $(1,000,500,250$, and $125 \mu \mathrm{g} / \mathrm{mL})$ of each materials $(0.02 \mathrm{~mL})$ composed of ethanol and Triton X-100 (0.9:0.1, v/v) were added to the wells and incubated at $24 \pm 1^{\circ} \mathrm{C}$. The percentage mortality of $\mathrm{J} 2$ was recorded by counting them after $24 \mathrm{~h}$ under a binocular microscope $(\times 40)$. Essential oils at a concentration of 1,000 $\mu \mathrm{g} / \mathrm{mL}$ that showed nematicidal activities more than $90 \%$ of the M. hapla J2 population were selected for the hatching inhibition experiments.

The hatching inhibition assays of six active essential oils against M. hapla eggs were evaluated under laboratory conditions. Approximately 130 to 170 nematode eggs in were introduced into six active essential oil solutions at a concentration of $500 \mu \mathrm{g} / \mathrm{mL}$ and incubated at $24 \pm 1^{\circ} \mathrm{C}$. Inhibitory effect of hatching was recorded after 7, 14, and 21 days, respectively. Controls consisted of the ethanol/Triton X-100 carrier solution in distilled water. All treatments had three replicated and were performed at least twice.

\section{Gas chromatography mass spectroscopy (GC/MS)}

Gas chromatography-mass spectroscopy (GC/MS) analyses of the active Alpinia galanga oil were performed using Agilent GC model 6890 fitted with MS detector (Agilent 5973 ) and a DB-5 silica capillary column (inner diameter $0.32 \mathrm{~mm}$; length $30 \mathrm{~m}$; film thickness $0.5 \mu \mathrm{m}$ ). Helium was used as carrier gas at the flow rate of $1.5 \mathrm{~mL} / \mathrm{min}$. The analytic conditions were as follows: ion source temperature, $280^{\circ} \mathrm{C}$; injector temperature, $250^{\circ} \mathrm{C}$; column temperature, $90^{\circ} \mathrm{C}$. Mass spectra were recorded over 50 to $600 \mathrm{amu}$ range with $70 \mathrm{eV}$. The split ratio use was 20:1. The identification of volatile constituents was based on the retention indices on the DB-5 silica capillary column, retention times, and mass spectra with the Wiley Registry of Mass spectral Data 7th edition.

\section{Data analysis}

The percentage mortality values of $\mathrm{J} 2$ were calculated from the formula: $\%=$ (number of dead $\mathrm{J} 2 /$ total number of J2) $\times 100$. Data were analyzed statistically by analysis of variance and means compared with Duncan's Multiple Range test $(P<0.05)$.

\section{Results and discussion}

Nematicidal activities of nine essential oils against $M$. hapla $\mathrm{J} 2$ were evaluated by 24 -well culture plate bioassay (Table 1). Based on the mortality of juveniles at a concentration of $125 \mu \mathrm{g} / \mathrm{mL}$, the most active essential oil was A. galanga (100\%), followed by C. carbi $(22.3 \%), E$. caryophyllata (9.4\%), C. zeylanicum (7.2\%), M. pulegium (2.4\%), and F. vulgare (2.1\%). However, L. intermedia $c v$. Grosso, $M$. viridiflora, and $M$. fragrans had no activity at the same concentration against $M$. hapla juveniles. Because of potent activity of six essential oils (A. galanga, C. carbi, E. caryophyllata, C. zeylanicum, M. pulegium, and F. vulgare) against $M$. hapla juveniles, the hatching inhibition of selected oils to M. hapla eggs was investigated using 24-well culture plate bioassay at a concentration of $500 \mu \mathrm{g} / \mathrm{mL}$ (Fig. 1). A. galanga was also effective at hatching inhibition, followed by C. zeylanicum, E. caryophyllata, F. vulgare, M. pulegium, and $C$. carbi. These results indicate that toxicity differences were related to that of susceptibility varies with the developmental stage. According to Wharton (2002), egg stage is the most resistant stage in the nematode developmental stages, due to its three-layer shell (vitelline layer, chitinous layer, and lipid layer).

Volatile constituents accounting $98.1 \%$ of A. galanga 
Table 1. Nematicidal activity of essential oils against Meloidogyne hapla second-stage juveniles ${ }^{\mathrm{a}}$

\begin{tabular}{lcccc}
\hline \multirow{2}{*}{ Samples $(\mu \mathrm{g} / \mathrm{mL})$} & \multicolumn{4}{c}{ Mortality $(\%) \pm \mathrm{SE}^{\mathrm{b}}$} \\
\cline { 2 - 5 } & 1,000 & 500 & 250 & 125 \\
\hline Alpinia galanga & $100 \mathrm{a}$ & $100 \mathrm{a}$ & $100 \mathrm{a}$ & $100 \mathrm{a}$ \\
Carum carbi & $100 \mathrm{a}$ & $100 \mathrm{a}$ & $59.0 \pm 2.3 \mathrm{~b}$ & $22.3 \pm 5.8 \mathrm{~b}$ \\
Cinnamonum zeylanicum & $100 \mathrm{a}$ & $95.9 \pm 0.5 \mathrm{a}$ & $27.1 \pm 2.6 \mathrm{c}$ & $7.2 \pm 1.4 \mathrm{c}$ \\
Eugenia caryophyllata & $100 \mathrm{a}$ & $98.2 \pm 0.4 \mathrm{a}$ & $30.1 \pm 4.5 \mathrm{c}$ & $9.4 \pm 2.6 \mathrm{c}$ \\
Foeniculum vulgare & $100 \mathrm{a}$ & $67.4 \pm 7.8 \mathrm{~b}$ & $7.8 \pm 2.4 \mathrm{~d}$ & $2.1 \pm 0.8 \mathrm{~d}$ \\
Lavandula intermedia cv. Grosso & $41.5 \pm 5.6 \mathrm{~b}$ & $23.1 \pm 7.2 \mathrm{c}$ & $0.0 \pm 0.0 \mathrm{e}$ & $0.0 \pm 0.0 \mathrm{~d}$ \\
Melaleuca viridiflora & $29.0 \pm 4.9 \mathrm{c}$ & $14.1 \pm 2.2 \mathrm{~d}$ & $0.0 \pm 0.0 \mathrm{e}$ & $0.0 \pm 0.0 \mathrm{~d}$ \\
Mentha pulegium & $100 \mathrm{a}$ & $98.7 \pm 1.2 \mathrm{a}$ & $10.3 \pm 3.4 \mathrm{~d}$ & $2.4 \pm 0.7 \mathrm{~d}$ \\
Myristica fragrans & $31.3 \pm 4.6 \mathrm{c}$ & $15.6 \pm 6.1 \mathrm{~d}$ & $0.0 \pm 0.0 \mathrm{e}$ & $0.0 \pm 0.0 \mathrm{~d}$ \\
Negative control & $2.6 \pm 0.5 \mathrm{~d}$ & - & - & - \\
\hline
\end{tabular}

${ }^{\mathrm{a}}$ Exposed for $24 \mathrm{~h}$.

${ }^{\text {b}}$ Different letters next to the values in the column indicate significant differences at $p<0.05$.

Table 2. Volatile constituents from rhizomes of Alpinia galanga oil identified by GC/MS

\begin{tabular}{|c|c|c|c|c|}
\hline Peak number & $\mathrm{RI}^{\mathrm{a}}$ & Retention time (min) & Components & Relative composition (\%) \\
\hline 1 & 943 & 6.54 & $\alpha$-Pinene & 2.23 \\
\hline 2 & 965 & 7.41 & $\beta$-Pinene & 2.54 \\
\hline 3 & 1010 & 8.25 & $p$-Cymene & 1.05 \\
\hline 4 & 1031 & 8.42 & 1,8-Cineole & 4.37 \\
\hline 5 & 1121 & 9.45 & Fenchone & 0.53 \\
\hline 6 & 1267 & 16.65 & Methyl cinnamate & 87.39 \\
\hline \multicolumn{4}{|c|}{ Total identified } & 98.11 \\
\hline \multicolumn{5}{|c|}{ Major grouped compounds } \\
\hline \multicolumn{4}{|c|}{ Monoterpene esters } & 87.39 \\
\hline \multicolumn{4}{|c|}{ Monoterpene hydrocarbons } & 5.82 \\
\hline \multicolumn{4}{|c|}{ Monoterpene ketones } & 0.53 \\
\hline \multicolumn{4}{|c|}{ Monoterpene oxides } & 4.37 \\
\hline
\end{tabular}

${ }^{\mathrm{a}}$ Retention indices (RI) were determined on DB-5 capillary column.

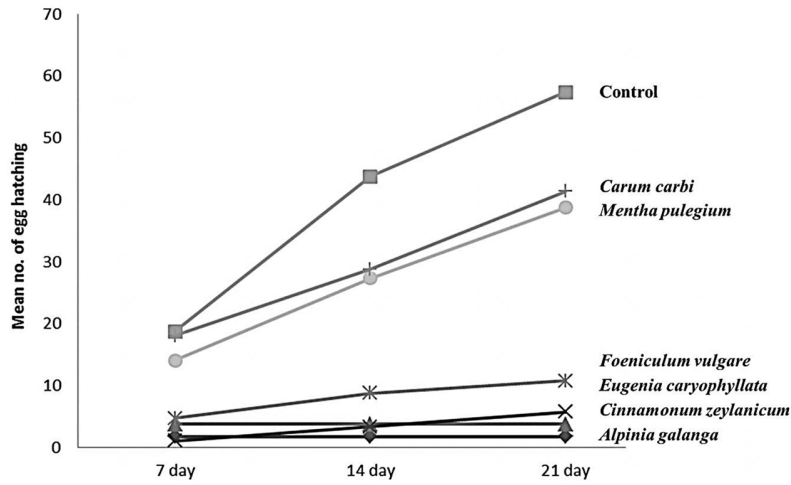

Fig. 1. Inhibitory effect of $500 \mu \mathrm{g} / \mathrm{mL}$ essential oils on hatching of Meloidogyne hapla eggs.

rhizomes oil were identified by GC/MS (Table 2). The identified compounds in A. galanga oil were methyl cinnamate
(87.39\%), 1,8-cineole (4.37\%), $\beta$-pinene $(2.54 \%), \alpha$-pinene $(2.23 \%), p$-cymene $(1.05 \%)$, and fenchone $(0.53 \%)$. The volatile constituents from $A$. galanga rhizomes oil were grouped as monoterpene ester (methyl cinnamate), monoterpene hydrocarbon ( $\alpha$-pinene, $\beta$-pinene, and $p$-cymene), monoterpene oxide (1,8-cineole), and monoterpene ketone (fenchone). Compared with the previous studies (Raina et al., 2014), the major components of A. galanga oil were 1.8-cineole (63.4\%), (E)- $\beta$-farnesene (8.4\%), eugenol acetate $(3.3 \%), \alpha$-terpineol $(2.8 \%)$, terpinen-4-ol $(2.8 \%)$, and $(E)$-methyl cinnamate $(0.2 \%)$. However, the occurrence of methyl cinnamate as major component in the A. galanga oil in the present study is not matched those of previous reports. The quantitative and compositional differences of chemical composition of plants 
are attributed to geographical origin, extraction methods, parts of herbs, chemotypes, and harvest conditions (Raina et al., 2002; Yang and Lee, 2013). Essential oil from various plants is used commercially sources of pesticides for insect control (Oka et al., 2000; Jeon et al., 2015). Several essential oils and their constituents have been reported to their nematicidal effect, such as Mentha spp., Origanum spp., Eucalypus spp., and Tagetes spp., and their components (alcohols, alkaloids, phenolics, and terpenoids) (Uhlenbroek et al., 1958; Belcher and Hussey, 1977; Oka et al., 2000; Pandey et al., 2000; Lee et al., 2011). Our study also demonstrated that essential oil from $A$. galanga rhizome had nematicidal effective against $M$. hapla juveniles and eggs. Therefore, natural nematicides based on plant extracts, essential oils, and phytochemicals could be beneficial as alternatives to pesticides for control nematodes. Further experiments are needed to evaluate the nematicidal efficacy under greenhouse and field conditions for the practical use of A. galanga rhizome-derived oil and its volatile constituents. Additionally, nematicidal constituents derived from A. galanga oil and mode of action need to be conducted.

\section{Acknowledgments}

This research was carried out with the support of Cooperative Research Program for Agriculture Science \& Technology Development (Project title: Distribution and occurrence of root-knot nematodes under greenhouse cultivation, Project No: PJ009309), Rural Development Administration, Republic of Korea.

\section{Literature Cited}

Barker, K. R. (1985) Nematode extraction and bioassays. In: Barker KR, Carter CC \& Sasser JN (eds). An advanced treatise on Meloidogyne, volume 2, pp. 19-35. North Carolina State University, Raleigh, NC, USA.

Belcher, J. V. and R. S. Hussey (1977) Influence of Tagetes patula and Arachis hypogaea on Meloidogyne incognita. Plant Dis. Reptr. 61:525-528.

Chitwood, D. J. (2002) Phytochemical-based strategies for nematode control. Ann. Rev. Phytopathol. 40:221-249.

Hong, T. K., J. K. Lee, J. W. Heo, S. I. Kim, D. R. Choi and Y. J. Ahn (2010) Toxicity of Kaempferia galanga rhizomederived extract and steam distillate to Meloidogyne incognita juveniles and eggs, and their effects on
Lycopersicon esculentum germination and growth. Nematol. 12:775-785.

Jeon, J. H., S. G. Lee and H. S. Lee (2015) Isolation of insecticidal constituent from Ruta graveolens and structureactivity relationship studies against stored-food pests (Coleoptera). J. Food Prot. 78:1536-1540.

Kim, S. I., J. K. Lee, Y. E. Na, S. T. Yoon and Y. J. Oh (2014) Nematicidal and ovicidal activities of Dryobalanops aromatic and Mentha haplocalyx var. piperascens-derived materials and their formulations against Meloidogyne incognita second-stage juveniles and eggs. Nematol. 16: 193-200.

Kim, S. J. and K. S. Whang (2012) Nematicidal effect of rootknot nematode (Meloidogyne incognita) by amino acids biochemical agent extracted from chicken feather. J. Appl. Biol. Chem. 55:247-252.

Lee, J. S., H. Y. Choo and D. W. Lee (2011) Nematicidal efficacy of herbal extracts against Meloidogyne hapla. Kor. J. Appl. Entomol. 50:315-324.

Nguyen, D. M. C., D. J. Seo, V. N. Nguyen, K. Y. Kim, R. D. Park and W. J. Jung (2013) Nematicidal activity of gallic acid purified from Terminalia nigrovenulosa bark against the root-knot nematode Meloidogyne incognita. Nematol. 15:507-518.

Oka, Y., S. Nacar, E. Putievsky, U. Ravid, Z. Yaniv and Y. Spiegel (2000) Nematicidal activity of essential oils and their components against the root-knot nematode. Phytopathol. 90:710-705.

Pandey, R., A. Kalra, S. Tandon, N. Mehrotra, H. N. Singh and S. Kumar (2000) Essential oils as potent sources of nematicidal compounds. J. Phytopathol. 148:201-202.

Raina, A. P., S. K. Verma and Z. Abraham (2014) Volatile constituents of essential oils isolated from Alpinia galanga Willd. (L.) and A. officinarum Hance rhizomes from North East India. J. Ess. oil Res. 26:24-28.

Raina, V. K., S. K. Srivastava and K. V. Syamasunder (2002) The essential oil of 'greater galanga' [Alpinia galalga (L.) Willd.] from the lower Himalayan region of India. Flavour. Fragr. J. 17:358-360.

Uhlenbroek, J. H. and J. D. Bijloo (1958) Investigations on nematicides. I. Isolation and structure of a nematicidal principle occurring in Tagetes roots. Recl. Trav. Chim. Pays. Bas. 77:1004-1008.

Wharton, D. A. (2002) Nematode survival strategies. In: Lee DL (ed.), The biology of nematodes, pp. 389-411. Taylor \& Francis, New York, USA.

Yang, J. Y. and H. S. Lee (2013) Verbenone structural analogues isolated from Artemesia aucheri as natural acaricides against Dermatophagoides spp. and Tyrophagus putrescentiae. J. Agric. Food Chem. 61:12292-12296. 


\title{
식물정유의 당근뿌리혹선충(Meloidogyne hapla)에 대한 살선충활성 및 방향성성분 분석
}

\author{
전주현 ${ }^{1,2} \cdot$ 고형래 $^{1} \cdot$ 김세종 $^{1} \cdot$ 이재국 ${ }^{1, *}$
}

1농촌진흥청 국립농업과학원 작물보호과, ${ }^{2}$ 한국한의학연구원 한의약융합연구부

요 약 본 연구는 뿌리혹선충의 친환경적 방제를 위하여 9종의 식물정유를 선발하여 당근뿌리혹선충 2령기 유충 과 알에 대한 살선충 및 부화억제 효과를 검정하였다. 당근뿌리혹선충의 2령기 유충에 대해 $125 \mu \mathrm{g} / \mathrm{mL}$ 로 검정한 결 과, Alpinia galanga 정유가 $100 \%$ 살선충활성을 나타냈고, Carum carbi (22.3\%), Eugenia caryophyllata (9.4\%), Cinnamonum zeylanicum (7.2\%), Mentha pulegium (2.4\%) 및 Foeniculum vulgare (2.1\%) 순으로 활성을 나타내었 다. 이들 중 A. galanga 정유를 이용하여 당근뿌리혹선충 알의 부화억제 활성을 검정한 결과, $500 \mu \mathrm{g} / \mathrm{mL}$ 농도로 처 리 후 7, 14, 21 일째까지 낮은 부화 활성을 나타내었다. 우수한 활성을 보인 A. galanga 정유의 활성 성분을 분석한 결과 methyl cinnamate 함유율이 가장 높았으며, 1,8 -cineole, $\beta$-pinene, $\alpha$-pinene, $p$-cymene이 주요 방향성 물질로 구성되어 있음을 확인할 수 있었다. 따라서 본 연구에서 선발한 A. galanga 정유가 당근뿌리혹선충의 친환경적 방제 수단으로 활용가능성이 있을 것으로 생각된다.

색인어 갈랑갈, 당근뿌리혹선충, 식물정유, 천연살선충제 